\title{
Sprawozdanie z Międzynarodowej Konferencji Naukowej „Realizacja zadań publicznych przez jednostki samorządu terytorialnego. Teoria. Orzecznictwo. Praktyka", Sandomierz, 21-23 maja 2017 r.
}

W dniach 21-23 maja 2016 r. w Sandomierzu odbyła się Międzynarodowa Konferencja Naukowa "Realizacja zadań publicznych przez jednostki samorządu terytorialnego. Teoria. Orzecznictwo. Praktyka". Jej organizatorami byli: Katedra Prawa Publicznego, Zakład Prawa Finansowego i Zakład Prawa Policyjnego Wydziału Prawa i Administracji Uniwersytetu Rzeszowskiego. Udział w niej wzięli wybitni przedstawiciele nauki prawa administracyjnego, prawa finansowego i postępowania administracyjnego ze wszystkich uniwersytetów w Polsce, a także z ośrodków akademickich w Europie (Turcja, Słowacja). Ponadto obecni byli radni i pracownicy samorządowi z Urzędu Miejskiego w Sandomierzu oraz gmin sąsiednich i starostwa powiatowego. Patronat honorowy nad konferencją objęli: Adam Jarubas - marszałek województwa świętokrzyskiego, Stanisław Masternak - starosta powiatu sandomierskiego oraz Marek Bronkowski - burmistrz Sandomierza. Obrady miały miejsce na zamku sandomierskim, który jest siedzibą Muzeum Okręgowego, a w drugim dniu - w zespole dworskim (hotel Sarmata).

Uroczystego otwarcia konferencji i przywitania przybyłych gości dokonali: prof. zw. dr hab. Elżbieta Ura - kierownik Katedry Prawa Publicznego, dr hab. Elżbieta Feret, prof. UR - kierownik Zakładu Prawa Finansowego, dziekan Wydziału Prawa i Administracji UR oraz prof. zw. dr hab. Stanisław Pieprzny - kierownik Zakładu Prawa Policyjnego. W powitaniu wskazano, że organizacja konferencji zbiega się $\mathrm{z}$ 27. rocznicą utworzenia samorządu terytorialnego w Polsce $\mathrm{w}$ wyniku przemian ustrojowych w $1990 \mathrm{r}$. Intencją organizatorów było przede wszystkim skoncentrowanie się na aktualnych problemach dotyczących zadań publicznych wykonywanych przez jednostki samorządu terytorialnego (j.s.t.), przy uwzględnieniu, że nie jest możliwe przedstawienie ich wszystkich. Przyjęto natomiast, że rozwój samorządu terytorialnego oraz jego pozycja sa gwarantem bezpieczeństwa w zakresie realizacji zadań publicznych dotyczących wspólnot mieszkańców. Prof. Elżbieta Ura podkreśliła obecność tak wielu znamienitych profesorów prawa, w tym tych, którzy brali bezpośredni udział w tworzeniu prawa samorządowego. Podziękowała też burmistrzowi miasta za pomoc w organizacji konferencji, objęcie jej patronatem i udział w obradach.

W części oficjalnej głos zabrał burmistrz Sandomierza Marek Bronkowski. Witając serdecznie wszystkich obecnych, zwrócił uwagę na potrzebę wymiany poglądów 
między praktykami a pracownikami nauki zajmującymi się problematyką samorządu terytorialnego. Na miejsce, w którym odbywały się obrady, czyli zamek sandomierski, zwrócił uwagę dyrektor Muzeum Okręgowego dr Dominik Abłamowicz, który również zaszczycił konferencję swoją obecnością, życząc owocnych obrad.

Obrady zostały podzielone na dwie sesje. Sesję pierwszą prowadziła prof. $z w . d r$ hab. Małgorzata Stahl (Uniwersytet Łódzki). Pierwszy z referentów, prof. UWr dr hab. Jerzy Korczak (Uniwersytet Wrocławski), wygłosił referat na temat decentralizacji i recentralizacji w administracji publicznej na przykładzie zadań własnych i zleconych jednostek samorządu terytorialnego. Występujący stwierdził, że w obliczu przyjętej w Konstytucji RP zasady decentralizacji wszelkie procesy recentralizacji są naruszeniem ustawy zasadniczej. Podkreślił, że jest to także naruszenie norm prawa międzynarodowego, do których przestrzegania Polska zobowiązała się przy każdorazowej ich ratyfikacji. Następnie wskazał, iż należy postulować odpowiednie zmiany w ustawodawstwie przywracające stan decentralizacji sprzed rozpoczęcia działań recentralizujących. Kolejny referat „Przekazywanie zadań i kompetencji przez organy jednostek samorządu terytorialnego" został wygłoszony przez prof. UAM dra hab. Krystiana Ziemskiego. W wystąpieniu podkreślono, że kwestie przekazywania, powierzania zadań i kompetencji oraz upoważnienia, jako pozostawiające nadal wątpliwości w orzecznictwie, wymagają bardziej szczegółowych opracowań doktrynalnych, a w następstwie ich ustaleń - dokonania odpowiednich prac nowelizacyjnych. W dalszej części spotkania głos zabrała prof. zw. dr hab. Barbara Adamiak (Uniwersytet Wrocławski), która wygłosiła referat „Uwagi o samodzielności organu samorządu terytorialnego w kształtowaniu treści rozstrzygnięcia sprawy indywidualnej decyzją administracyjną". Zdaniem prelegentki w przyjętych rozwiązaniach prawnych można wskazać na instytucje, które ograniczają pełną samodzielność samorządu terytorialnego. Wynika to z konieczności współdziałania organów administracji publicznej, konieczności uwzględniania w ustaleniach faktycznych opinii biegłych z powodu braku wiedzy w danej dziedzinie, zapewnienia ochrony praw jednostki przed ponownym wadliwym rozpoznaniem i rozstrzygnięciem sprawy. Pomimo tych ograniczeń ostateczna treść rozstrzygnięcia sprawy indywidualnej przynależy jednak do właściwości organu samorządu terytorialnego. Ostatni referat w pierwszej sesji „Finansowania zadań j.s.t. w świetle zasady adekwatności na tle orzecznictwa Trybunału Konstytucyjnego" został wygłoszony przez dr Anetę Szymczak i dr Magdalenę Budziarek z Uniwersytetu Łódzkiego. W swoim wystąpieniu prelegentki przybliżyły uczestnikom konferencji kwestię wyposażania j.s.t. w środki konieczne do realizacji nałożonych na nie zadań, co jest wciąż przedmiotem licznych wypowiedzi doktryny i judykatury. Wskazały również wiele orzeczeń Trybunału Konstytucyjnego dotyczących tego zagadnienia. W dalszej kolejności wygłoszone zostały krótkie wystąpienia: prof. UKSW dr hab. Ireny Lipowicz (Uniwersytet Kardynała Stefana Wyszyńskiego w Warszawie), która zwróciła uwagę na ideę samorządności i próby jej ograniczania, prof. zw. dra hab. Bogdana Dolnickiego z Uniwersytetu Śląskiego w Katowicach, prof. zw. dra hab. Bronisława Sitka z Uniwersytetu Społeczno-Humanistycznego w Warszawie oraz dra hab. Piotra Szreniawskiego z Uniwersytetu Marii Curie-Skłodowskiej w Lublinie. Następnie uczestnicy konferencji przeszli do dyskusji, w której udział wzięli: prof. zw. dr hab. Krystyna Piotrowska-Marczak (Uniwersytet Łódzki), prof. 
zw. dr hab. Mirosław Stec (Uniwersytet Jagielloński w Krakowie), dr hab. Marek Zdebel (Uniwersytet Śląski w Katowicach), prof. UG dr hab. Tomasz Bąkowski (Uniwersytet Gdański), prof. WSIiZ dr hab. Marian Liwo (Wyższa Szkoła Informatyki i Zarządzania w Rzeszowie). W ramach dyskusji odniesiono się do zagadnień podnoszonych w referatach, a nadto zwrócono uwagę na trafność doboru tematyki konferencji. Podkreślono wielowątkowość poruszanych tematów oraz wskazano liczne problemy, z którymi samorządowcy i organy wszystkich jednostek samorządu terytorialnego w Polsce spotykają się na co dzień.

Sesję drugą w pierwszym dniu prowadził prof. zw. dr hab. Bogdan Dolnicki z Uniwersytetu Śląskiego w Katowicach. Pierwszy referat "Wykonywanie zadań publicznych przez gminy w perspektywie podatku od towarów i usług" wygłosił dr hab. Piotr Przybysz (Uniwersytet Warszawski). Referent wskazał, że spojrzenie na zagadnienia wykonywania zadań publicznych przez gminy przez pryzmat przepisów o podatku od towarów i usług pokazuje, że sposób postrzegania podmiotowości w podatku VAT gminy oraz jej jednostek organizacyjnych nieposiadających osobowości prawnej uległ w ostatnich latach uproszczeniu i zbliża się do sposobu widzenia podmiotowości prawnej gminy w prawie cywilnym. Kolejny prelegent, prof. UŁ dr hab. Michał Kasiński (Uniwersytet Łódzki), poruszył temat policyjnej funkcji samorządu powiatowego. Stwierdził on, że funkcja policyjna samorządu powiatowego została oparta na założeniu, iż nie sprowadza się ona do wpływu na miejscową jednostkę Policji i inne policje administracyjne, lecz obejmuje znacznie szerszy zakres ochrony szczególnie cenionych dóbr: życia, zdrowia, mienia, środowiska i przyrody. Ostatni referat w tej sesji „Konflikty uzemnej samospravy a skolskiej samosprawy pri menovani riaditel'a skoly" (Konflikt między samorządem a autonomia szkół w mianowaniu dyrektora szkoły) wygłosił doc. JUDr. Jozef Tekeli, PhD. (Uniwersytet Pavla Jozefa Šafàrika w Koszycach). Następnie rozpoczął się dalszy ciąg dyskusji, w której odnoszono się nie tylko do prezentowanych wystąpień, ale również w szerszym zakresie do zadań publicznych realizowanych przez jednostki samorządu terytorialnego. W dyskusji głos zabrali: prof. UTH dr hab. Helena Kisilowska (Uniwersytet Technologiczno-Humanistyczny im. Kazimierza Pułaskiego w Radomiu), prof. zw. dr hab. Bogdan Dolnicki (UŚ), dr Andrzej Pakuła (UWr), prof. zw. dr hab. Małgorzata Stahl (UŁ), prof. UMCS dr hab. Janusz Niczyporuk, prof. UAM dr hab. Krystian Ziemski. Dyskusja odnosiła się też do zakresu samorządności na Słowacji, a to w związku z zagadnieniami zaprezentowanymi przez prof. J. Tekelego. Podkreślono także, że międzynarodowe konferencje naukowe o charakterze interdyscyplinarnym i w wymiarze międzynarodowym dają możliwość szerszego spojrzenia na problematykę związaną z samorządem terytorialnym oraz mogą być podstawą do wdrożenia rozwiązań, które sprawdziły się w innych państwach.

W drugim dniu obrady prowadzone były w dwóch grupach: w ramach panelu administracyjnego i panelu finansowego. Pierwszej sesji w panelu administracyjnym przewodniczyła prof. zw. dr hab. Barbara Adamiak. Referaty w tym dniu odnosiły się już do konkretnych zadań samorządu terytorialnego regulowanych prawem administracyjnym materialnym. Prof. UWM dr. hab. Jarosław Dobkowski (Uniwersytet Warmińsko-Mazurski w Olsztynie) skupił się na podstawowych zagadnieniach dotyczących zadań samorządu terytorialnego w zakresie zapewnienia bezpieczeństwa osób przebywających na obszarach wodnych, zwracając 
uwagę na rolę organów gminy w tym zakresie, sprowadzającą się do tworzenia warunków do bezpiecznego pływania, kąpieli i uprawiania sportów wodnych oraz współdziałania z innymi organami, instytucjami i organizacjami. Kolejne wystąienie, dra Rafała Budzisza (Uniwersytet Łódzki), dotyczyło nowych zadań samorządu terytorialnego w sferze ochrony zdrowia. Prelegent podkreślił, że ustawa o zmianie ustawy o działalności leczniczej oraz niektórych innych ustaw, wbrew twierdzeniom projektodawcy, wprowadziła nowe zadania dla j.s.t. w sferze ochrony zdrowia. $Z$ jednej strony umożliwia jednostkom samorządowym zwiększenie dostępności świadczeń opieki zdrowotnej dla swoich mieszkańców, jednak z drugiej - nie wprowadza jasnych reguł dotyczących podziału zadań z zakresu ochrony zdrowia pomiędzy administracją rządową i samorządowa, nie określa przejrzystych zasad finansowania świadczeń zdrowotnych i zasad ich wykonywania. Niejasne pozostają również procedury wyłaniania podmiotu realizującego nowe zadania oraz wzajemne relacje świadczeń finansowych przez NFZ i jednostki samorządu. W dalszej części wystąpił prof. PW dr hab. Robert Suwaj (Politechnika Warszawska), prezentując referat "Opłata infrastrukturalna - oczekiwania i obawy". W swoim wystąpieniu zwrócił uwage na to, że opłata infrastrukturalna ma w założeniu projektodawcy zastąpić dotychczas funkcjonującą opłatę adiacencką oraz w pewnym sensie objąć również swym zakresem tzw. rentę planistyczną. Zagadnienie to wywołuje wiele dyskusji i obaw. Kolejny referat dotyczył ochrony praw osób niepełnosprawnych na tle zjawiska prywatyzacji zadań publicznych jednostek samorządu terytorialnego. Referującą była prof. zw. dr hab. Lidia Zacharko z Uniwersytetu Śląskiego w Katowicach. Podkreśliła ona, że miarodajnym kryterium rozstrzygnięć o granice prywatyzacji zadań publicznych winno być nie tylko kryterium opłacalności, ale kryterium interesu publicznego, tj. zagwarantowanie ciągłości zaspokajania potrzeb. Wspomniany interes publiczny jest szczególnie ważny przy prywatyzacji usług w dziedzinach wrażliwych, czyli pomocy społecznej, oświacie, służbie zdrowia czy w zakresie zatrudniania osób niepełnosprawnych. Ustawodawca, wprowadzając granice prywatyzacji zadań publicznych, powinien brać pod uwagę implikacje, jakie mogą nastąpić dla interesu społecznego czy interesu jednostki. Sesję zakończono dyskusja, którą podsumowała prof. zw. dr hab. Barbara Adamiak, stwierdzając, że katalog zadań jednostek samorządu terytorialnego ma charakter otwarty i wciąż pojawiają się nowe, które ze względu na interes publiczny należy zaspokajać.

Kolejnej sesji przewodniczył prof. zw. dr hab. Dariusz Kijowski (Uniwersytet w Białymstoku). Pierwszy referat w tej części wygłosiła prof. UŁ dr hab. Barbara Jaworska-Dębska (Uniwersytet Łódzki). Wystąpienie dotyczyło charakteru decyzji w sprawie zezwolenia na sprzedaż detaliczną napojów alkoholowych. Zdaniem referentki zezwolenia na sprzedaż detaliczną stanowią bezpośredni instrument ograniczania dostępności alkoholu, stanowią też element gminnej polityki dotyczącej alkoholu i problemów z nim związanych. Prelegentka zwróciła również uwagę na to, że wydawanie zezwoleń, a także odmowa ich wydania są poddane kontroli społecznej znacznie częściej niż działalność jurysdykcyjna gmin w innym przedmiocie. Sesję zakończył referat wygłoszony przez prof. zw. dra hab. Marka Szewczyka (Uniwersytet im. Adama Mickiewicza w Poznaniu) na temat samodzielności gmin i wydawania decyzji o warunkach zabudowy i zagospodarowaniu terenu. 
Równolegle z panelem administracyjnym odbywał się panel finansowy prowadzony przez prof. zw. dr hab. Krystynę Piotrowską-Marczak. Pierwszy referat wygłosił Assist. Prof. dr Mehmet Alpertunga Avci (Uniwersytet Atatürka, Erzurum, Turcja). Tematem wystąpienia było przejście od lokalnego rządzenia do samorządności („The transition from local governing to local governance"). Następnie dr Paweł Majka z Uniwersytetu Rzeszowskiego wygłosił referat dotyczący elastyczności budżetu jako gwarancji skutecznej realizacji zadań przez jednostki samorządu terytorialnego, w którym wskazał, że finansowanie zadań j.s.t. wymaga, by budżety, w których zaplanowano wydatki, były elastyczne w stopniu umożliwiającym poniesienie wydatków w sposób efektywny oraz z wykorzystaniem właściwych metod i środków. Kolejną prelegentką była prof. UR dr hab. Elżbieta Feret (Uniwersytet Rzeszowski), która przedstawiła referat dotyczący gromadzenia i rozdysponowywania środków publicznych $\mathrm{w}$ gminie na podstawie metody budżetowania brutto. W wystąieniu podkreśliła, że ustawodawca nadał gminie liczne kompetencje do działania w ramach środków publicznych objętych budżetem gminnym. Uprawnienia te są jak najbardziej zasadne, zważywszy na fakt, że gmina jest podstawową jednostką samorządu terytorialnego. Referująca podkreśliła jednak, iż nadanie gminie tak wielu uprawnień łączących się z koniecznością korzystania ze środków zawartych w budżecie w ramach metody budżetowania brutto może w praktyce oznaczać niewystarczającą ich ilość, a co się z tym wiąże - konieczność działania opartego na metodzie budżetowania netto lub wręcz prywatyzowania gminnych zadań publicznych. Następny referat w panelu finansowym wygłosił dr Jarosław Czerw (Wyższa Szkoła Ekonomii i Innowacji w Lublinie). Jego wystąpienie "Zastępcze ustalenie budżetu jako nadzwyczajny tryb ustalenia budżetu j.s.t.” wskazało, że po ustaleniu budżetu jednostki samorządu terytorialnego przez regionalną izbę obrachunkową kompetencje dotyczące budżetu powracają do organów j.s.t. Jako kolejny wystąpił dr hab. Marek Zdebel (Uniwersytet Śląski w Katowicach), przedstawiając referat "Władztwo podatkowe gmin samorządowych". Głównym celem wystąpienia było wykazanie m.in., że w warunkach ustawodawstwa polskiego samorządy terytorialne, w tym gminy, posiadają zagwarantowane konstytucją ograniczone władztwo podatkowe, które dotyczy tylko niektórych należności podatkowych zasilających budżety gminne i sprowadza się do kształtowania w ramach przepisów ustaw podatkowych oraz wprowadzenia dodatkowych zezwoleń przedmiotowych. Panel finansowy został zakończony wygłoszonym przez dr Dominikę Łukawską-Białogłowską (Uniwersytet Łódzki) referatem na temat zapewnienia środków na wypłatę nauczycielskiego dodatku uzupełniającego w kontekście gromadzenia dochodów przez jednostki samorządu terytorialnego.

Po zakończeniu wszystkich referatów odbyła się wspólna dyskusja podsumowująca poszczególne wystąpienia, a także całą konferencję. Uczestnicy podkreślili, że analiza zagadnień przedstawionych przez poszczególnych prelegentów prowadzi do wniosku, iż nie jest możliwe przedstawienie wszystkich aktualnych problemów jednostek samorządu terytorialnego z teoretycznego i praktycznego punktu widzenia. Niewątpliwie, debaty, w ramach których spotykają się przedstawiciele nauki i praktyki z zakresu prawa administracyjnego i finansowego, pozwalają szerzej spojrzeć na funkcjonowanie samorządu terytorialnego i rozpatrzyć różne aspekty jego działalności. Podkreślono, że uchwalenie budżetu ma zasadnicze znaczenie 
dla realizacji zadań przez gminy, powiaty i województwa, co jest ściśle związane $\mathrm{z}$ realizacją szeroko rozumianego celu publicznego. Zwrócono także uwagę na to, że temat konferencji dotyczący realizacji zadań publicznych przez jednostki samorządu terytorialnego jest nadal aktualny i skłania do przemyśleń związanych $\mathrm{z}$ miejscem samorządu terytorialnego w ewoluującym polskim systemie prawnym. Wysoki poziom merytoryczny wystapień i dyskusji oraz niepowtarzalny urok miejsca obrad - miasta królewskiego Sandomierza - na długo pozostaną w pamięci.

Paulina Ura, Ewa Kubas DOI: 10.14746/spp.2017.2.18.13 